\title{
Microzooplankton Grazing and Phytoplankton Growth in a Chinese Lake
}

\author{
Panpan Liu ${ }^{1,2}$, Long Wang ${ }^{1,2}$, Xue Xia ${ }^{1,2}$, Lei Zeng ${ }^{1,2}$, Qiaohong Zhou ${ }^{1 *}$, \\ Biyun Liu ${ }^{1}$, Feng $\mathrm{He}^{1}$, Zhenbin $\mathrm{Wu}^{1}$ \\ ${ }^{1}$ State Key Laboratory of Freshwater Ecology and Biotechnology, Institute of Hydrobiology, \\ Chinese Academy of Sciences, Wuhan, China \\ ${ }^{2}$ University of Chinese Academy of Sciences, Beijing, China
}

Received: 13 September 2017

Accepted: 21 January 2018

\begin{abstract}
Microzooplankton plays an important role in controlling the standing crop of phytoplankton and primary production. However, research on microzooplankton grazing has mainly focused on the ocean and only rarely on eutrophic lakes. In this study we investigated plankton community structures, microzooplankton grazing rates $(m)$, and phytoplankton growth rates $(\mu)$ in order to explore microzooplankton grazing in 2 eutrophic sub-lakes of West Lake, Hangzhou, China (Waihu and Xilihu). Results showed that Pseudanabaena sp. was dominant in Waihu without submerged macrophytes, and the larger phytoplankton $(>2 \mu \mathrm{m})$ biomass was higher than the picophytoplankton $(<2 \mu \mathrm{m})$ biomass. However, Xilihu with macrophytes growing was mainly composed of diatoms and green algae, and there was no significant difference between larger phytoplankton and picophytoplankton biomass. Furthermore, in West Lake, the values of $m$ (ranging from 1.58 3.33/d) and $\mu$ (ranged from 1.38 3.05/d) were higher than those in the ocean. The higher $m, \mu$, and relative preference index (RPI) for picophytoplankton in Waihu indicated that microzooplankton had a significant size-selective grazing on picophytoplankton. However, no significant size-selection was found in Xilihu. These different responses of plankton in Waihu and Xilihu might explain why larger phytoplankton occupy a dominant position in eutrophic lakes.
\end{abstract}

Keywords: microzooplankton grazing, phytoplankton growth, size-selection, submerged macrophyte, eutrophic lakes

\section{Introduction}

The proposal and development of microbial loop [1] have changed people's understanding of the energy transfer process of the plankton ecosystem. Microzooplankton grazing plays an important role in controlling the standing crop of phytoplankton and primary production [2-3]. In estuaries, microzooplankton grazed $79 \%$ of primary productivity [3]. In freshwater, microzooplankton consumed $83 \%$ of the standing crop of phytoplankton and $76 \%$ of primary production [4], and about $88 \%$ of the available microzooplankton was consumed by the mesozooplankton as against only $51 \%$ of the phytoplankton [5]. This demonstrated the important role of microzooplankton in food energy transfer processes.

*e-mail: qhzhou@ihb.ac.cn 
Recent studies have shown that microzooplankton grazing on phytoplankton had size-selection [6-8], and in different areas microzooplankton showed different feeding preferences for differently sized phytoplankton. For instance, microzooplankton preferred to graze on larger-sized $(>3 \mu \mathrm{m})$ phytoplankton in the tropical oligotrophic marine [6]. In the bay area, microzooplankton mostly preferred to graze on picophytoplankton $(<2 \mu \mathrm{m})$, which was growing faster but had the lowest biomass component of the phytoplankton [7]. Microzooplankton grazed more on picophytoplankton and autotrophic nanoflagellates than on diatoms, and the dynamics of predator and prey population are almost balanced in water in which smaller phytoplankton were dominant [8]. Overall, microzooplankton grazing is an important process, controlling the biomass and composition of phytoplankton. In soda lakes, a strong structuring effect of rotifers and large ciliates on microbial plankton communities is assumed, especially in times of high consumer biomass [9].

However, studies on microzooplankton grazing effect on phytoplankton are mostly concentrated on the oceans and rarely conducted on the feeding selection in eutrophic freshwater. Their impacts on phytoplankton community structure were less known. And the spatial and seasonal variations observed on the abundance of the major groups of microzooplankton can be attributed to the influence of salinity and phytoplankton standing stock [10-11]. In recent years, the technique of submerged macrophyte reconstruction has been applied during eutrophic lakes restoration [12], but the influence of submerged vegetation on microzooplankton feeding behavior was still unknown.

In this study, eutrophic West Lake in Hangzhou, China, was taken as the object of study, and the microzooplankton grazing rates and phytoplankton growth rates were measured by the dilution method. Firstly, the grazing rate and phytoplankton growth rate in freshwater were studied. Then the selective feeding of microzooplankton on differently sized phytoplankton in freshwater lakes was also studied. Thus, this study will provide theoretical and technical support for the restoration of eutrophic water bodies.

\section{Materials and Methods}

\section{Sampling Station}

West Lake (lat. $30^{\circ} 24^{\prime} \mathrm{N}$, long. $120^{\circ} 15^{\prime} \mathrm{E}$ ), an urban landscape lake in Hangzhou, China, has been listed on the world cultural heritage list in 2011. The eutrophication in West Lake has attracted wide attention. In order to avert human influence we selected for study Waihu and Xilihu, two adjacent sub-lakes (Fig. 1). X1, X2, X3, and $\mathrm{X} 4$ in Xilihu represent the sampling sites with naturally growing submerged macrophytes. W1 and W2 represent the sampling stations without submerged macrophytes. This investigation was carried out in summer and winter 2016. Water samples at each sampling site were collected [13] to measure the water quality parameters (nitrogen, phosphorus, and chlorophyll a (Chl a)).

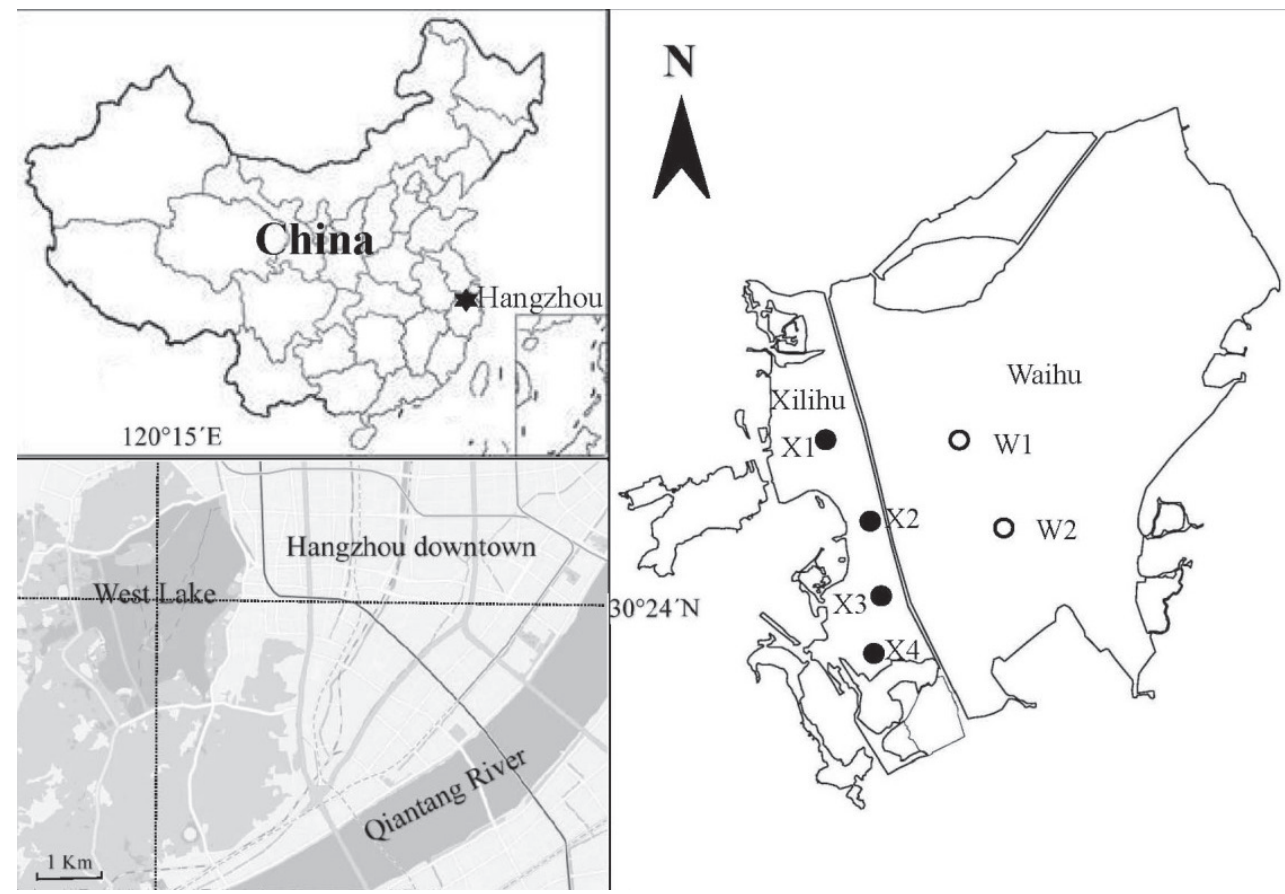

Fig. 1. Sampling sites for dilution experiments in the sub-lakes (Waihu and Xilihu) of West Lake in Hangzhou China during summer and winter 2016; the black circle indicates experimental sites with submerged macrophytes while the white circle indicates that no submerged macrophyte existed. 
Table 1. Distribution of submerged macrophytes and N:P ratio in Waihu and Xilihu, 2sub-lakes of the West Lake (the number of replicates was 3 at each sampling station).

\begin{tabular}{|c|c|c|c|c|c|}
\hline Season & Date & Sub-lakes & N:P ratio & Dominant macrophytes species & Other macrophytes \\
\hline \multirow{2}{*}{ Summer } & $07 / 15 / 2016$ & Xilihu & $48.07 \pm 8.35$ & Najas marina, Vallisneria natans & $\begin{array}{c}\text { Myriophyllum spicatum, } \\
\text { Ceratophyllum demersum }\end{array}$ \\
\cline { 2 - 7 } & $07 / 20 / 2016$ & Waihu & $11.45 \pm 0.66$ & & \\
\hline \multirow{2}{*}{ Winter } & $11 / 28 / 2016$ & Xilihu & $114.03 \pm 12.54$ & $\begin{array}{c}\text { Ceratophyllum demersum, } \\
\text { V. natans }\end{array}$ & \\
\cline { 2 - 7 } & $12 / 03 / 2016$ & Waihu & $46.12 \pm 0.42$ & & \\
\hline
\end{tabular}

Each water sample had 3 replicates. The water temperature and dissolved oxygen (DO) were measured in-situ via a Hach portable multiparameter probe (USA). The water depths of dilution experiment sampling sites were $0.8 \sim 2.9 \mathrm{~m}$, the water temperature was $31.1 \sim 31.9^{\circ} \mathrm{C}$ in summer and $13.3 \sim 14.3^{\circ} \mathrm{C}$ in winter, and the DO concentration was $6.09 \sim 9.26 \mathrm{mg} / \mathrm{L}$ in summer and $10.08 \sim 11.59 \mathrm{mg} / \mathrm{L}$ in winter. The distribution of submerged macrophyte and the N:P ratio in Waihu and Xilihu are shown in Table 1. In Xilihu, the dominant species of submerged vegetation in summer were Najas marina and Vallisneria natans, and in winter were Ceratophyllum demersum and $V$. natans. The N:P ratios were 48 114 in Xilihu, while the N:P ratios were 11 46 in Waihu, indicating that those 2 sub-lakes had a higher $\mathrm{N}: \mathrm{P}$ ratio.

\section{Identifying and Enumerating Planktonic Assemblages}

One-L water samples from each sampling sites were collected, and $10 \mathrm{~mL}$ of Lugo reagent were added, then brought to the laboratory. After settling for 24 hours, the water samples were concentrated to $50 \mathrm{~mL}$ using the siphon method, and the sub-samples were preserved for microscopic analysis and counting.

For the enumeration of phytoplankton cells, the subsamples were analyzed by microscope. The specimens were counted under a normal light microscope (Olympus BX53) at $400 \times$ magnification in $0.1 \mathrm{~mL}$ counting chambers [14].The rotifera and protozoan were identified according to the identification keys of Wang and Shen et al. [15-16], and the specimens were counted using a normal light microscope (Olympus BX53) at 100× and $200 \times$ magnification, respectively. All plankton samples were collected and processed in triplicate.

\section{Dilution Experiment}

The dilution method [17] was used to estimate microzooplankton grazing rate and phytoplankton growth rate. The theory, assumptions, and method for the dilution experiment have been described by Landry et al. [18].

Dilution experiments were conducted at 6 stations during summer and winter 2016. Surface water was collected and pre-screened with a $200 \mu$ m nylon netting for dilution experiments at each station. Particle-free water was obtained by filtering the surface water through a filter with a $0.22 \mu \mathrm{m}$ pore and filtered water was prepared a day in advance because of the large volume needed and the high biomass levels: filters clogged after passing about $250 \mathrm{~mL}$. Filtered water was stored in polyethylene bottles in the dark. All the bottles, containers, and filters were soaked in $10 \% \mathrm{HCl}$ for more than $10 \mathrm{~h}$, and thoroughly washed with deionized water and MiliQ-water before use. Particle-free water and unfiltered surface water was mixed and filled the $2 \mathrm{~L}$ polycarbonate bottles without air bubbles. Five dilution treatments of $10 \%, 25 \%, 50 \%$, $75 \%$, and $100 \%$ unfiltered surface water were prepared for all experiments. All bottles were not enriched with additional nutrients. All bottles were tied to a line below surface water about $25 \mathrm{~cm}$ and incubated in-situ for $24 \mathrm{~h}$. In order to avoid the effect of feeding rhythm on the results, the dilution experiment of different dates should be carried out between 09:00 and 10:30 every morning [19].

Surface water was filtered through $\mathrm{GF} / \mathrm{F}$ for total $\mathrm{Chl}$ a. In addition, surface water was filtered through a sequence of a $2 \mu \mathrm{m}$ pore polycarbonate filter and $\mathrm{GF} / \mathrm{F}$ for size-fractionated $\mathrm{Chl}$ a of the large-sized $(>2 \mu \mathrm{m})$ and picophytoplankton $(<2 \mu \mathrm{m})$. The filters were extracted in $90 \%$ acetone in the dark at $4^{\circ} \mathrm{C}$ for $24 \mathrm{~h}$. The $\mathrm{Chl}$ a concentration was measured by Spectrophotometry using a Shimadzu Designs Model UV-1800 spectrophotometer [13].

Assuming an exponential growth model, the net growth rate $\left(k_{d}\right)$ of phytoplankton in a dilution treatment was calculated according to the formula $k_{d}=\ln$ $\left(P_{t} / d P_{o}\right)$, where $d$ is the dilution factor (the proportion of unfiltered surface water), $P$ is the $\mathrm{Chl}$ a concentration after incubation, and $P_{o}$ is the initial $\mathrm{Chl} a$ concentration. Phytoplankton growth rates $(\mu)$ and microzooplankton grazing rates $(m)$ in situ were estimated from linear regressions of net growth rate $(k)$ vs. dilution factor $(d)$.

Grazing selectivity for size-fractioned phytoplankton was analyzed following the relative preference index (RPI) [20].

$$
R P I=\frac{\left[\text { mchla }_{i}\right] / \sum\left[\text { mchla }_{i}\right]}{\left[\text { chla }_{i}\right] / \sum\left[\text { chla }_{i}\right]}
$$



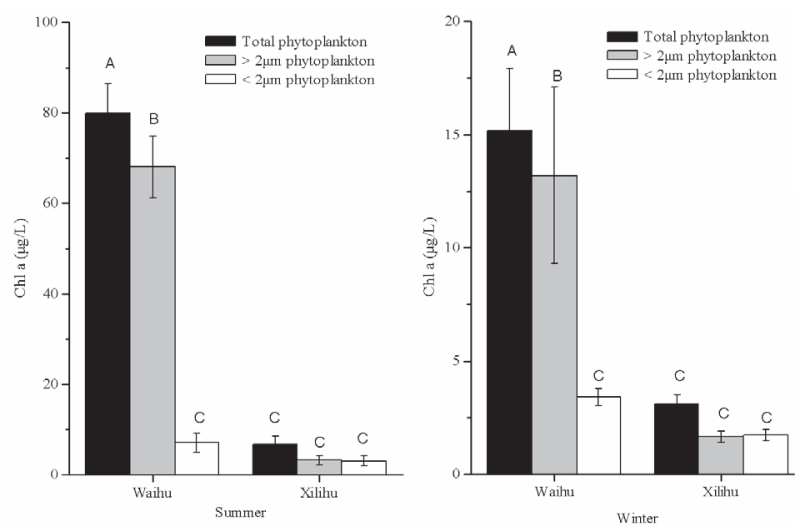

Fig. 2. Chl a concentration of the size-fraction phytoplankton of Waihu and Xilihu during summer and winter (one-way ANOVA, letters $\mathrm{A}, \mathrm{B}$, and $\mathrm{C}$ represent the significant differences at $p<0.05$ among the columns; the number of replicates was 3 at each sampling station).

...where mchla $_{i}$ is the amount of daily grazed Chl a ( $\mu \mathrm{g} \mathrm{L}-1 / \mathrm{d}$ ), subscript $i$ refers to each fraction size analyzed, and chla is the initial concentration of $\mathrm{Chl}$ a $(\mu \mathrm{g} / \mathrm{L})$. RPI $>1$ indicates positive selection and vice versa.

\section{Data Analysis}

All the statistical analyses were conducted by IBM SPSS Statistics 20.0. The figures were created by the Origin 8.0 program.

\section{Results}

\section{Microzooplankton, Phytoplankton Community Structure, and Chl a Concentration}

The densities of microzooplankton and phytoplankton, and $\mathrm{Chl}$ a concentration in Waihu were significantly higher than those in Xilihu in 2 seasons (Independent $\mathrm{t}$ test, $p<0.05$ ). Ciliates and rotifers were major components of microzooplankton, and the dominant species of rotifera were Brachionus and Polyarthra dolichoptera in Waihu, while dominant species of microzooplankton in Xilihu were Trichocerca, KeratelIa, and nauplii. Cyanobacteria were the main component in Waihu, where Pseudanabaena sp. dominated. Phytoplankton in Xilihu was mainly composed of diatoms and green algae. Moreover, the Chl a concentration of larger phytoplankton $(>2 \mu \mathrm{m})$ was significantly higher than picophytoplankton $(<2 \mu \mathrm{m})$ in Waihu, while no significant difference was found in Xilihu (one-way ANOVA, $p<0.05$, Fig. 2).

\section{Microzooplankton Grazing and Phytoplankton Growth}

The values of $m$ were $1.58 \sim 3.33 / \mathrm{d}$, and $\mu$ were $1.38 \sim 3.05 / \mathrm{d}$ in West Lake (Table 3). In summer, the values of $m$ had no significant difference between Waihu and Xilihu, and neither was the $\mu$. Nevertheless, both $m(2.94 \pm 0.39 / \mathrm{d})$ and $\mu(2.35 \pm 0.24 / \mathrm{d})$ in Waihu were higher than those in Xilihu $(2.03 \pm 0.20 / \mathrm{d} ; 1.86 \pm 0.21 / \mathrm{d}$, respectively; Table 3).

\section{Microzooplankton Size-Selective Grazing}

The microzooplankton grazing rate on differently sized phytoplankton is shown in Table 4. In winter, microzooplankton grazing rate on larger $(>2 \mu \mathrm{m})$ phytoplankton in Waihu $(3.55 \pm 0.11 / \mathrm{d})$ was significantly higher than in Xilihu $(1.86 \pm 0.18 / \mathrm{d})$ (independent $\mathrm{t}$ test, $p<0.05$ ). The larger phytoplankton growth rate in Waihu $(2.73 \pm 0.09 / \mathrm{d})$ was also significantly higher than in Xilihu $(1.73 \pm 0.16 / d)$. Both rates had no significant difference between Waihu and Xilihu in summer. Besides, both of the 2 rates on picophytoplankton also had no significant difference between Waihu and Xilihu either in summer or in winter.

The RPI of microzooplankton selective grazing on differently sized phytoplankton is shown in Fig. 3. Higher RPI for microzooplankton grazing on picophytoplankton was more significant than on larger-sized phytoplankton (independent t test, $p<0.05$ ) in Waihu during summer and winter. Nevertheless, no significant difference between RPI index for larger phytoplankton and picophytoplankton occurred in Xilihu.

\section{Correlations between Microzooplankton Grazing, Phytoplankton growth, and Environmental Variables}

The $m$ was positively correlated with $\mu$ ( $\mathrm{r}=0.94$, $p<0.01$, Table 5). The Chl a concentration of

Table 2. Phytoplankton density (cells/L, mean \pm se) and microzooplankton density (ind/L, mean $\pm \mathrm{se}$ ) of all in-situ dilution experiment sites during summer and winter; different letters in the same column in the same season indicate significant differences (independent $t$ test, $p<0.05$; the number of replicates was 3 at each sampling station).

\begin{tabular}{|c|c|c|c|}
\hline \multirow{2}{*}{ Season } & Sub-lakes & Phytoplankton (cells/L) & Microzooplankton (ind/L) \\
\hline \multirow{2}{*}{ Summer } & Xilihu & $5.55 \pm 0.85 \times 10^{6} \mathrm{~A}$ & $6,560.25 \pm 1,427.89 \mathrm{~A}$ \\
\cline { 2 - 4 } & Waihu & $371.25 \pm 30.24 \times 10^{6} \mathrm{~B}$ & $18,800.00 \pm 1,947.33 \mathrm{~B}$ \\
\hline \multirow{2}{*}{ Winter } & Xilihu & $0.78 \pm 0.17 \times 10^{6} \mathrm{~A}$ & $706.25 \pm 96.56 \mathrm{~A}$ \\
\cline { 2 - 4 } & Waihu & $18.10 \pm 5.07 \times 10^{6} \mathrm{~B}$ & $3,275.00 \pm 105.08 \mathrm{~B}$ \\
\hline
\end{tabular}




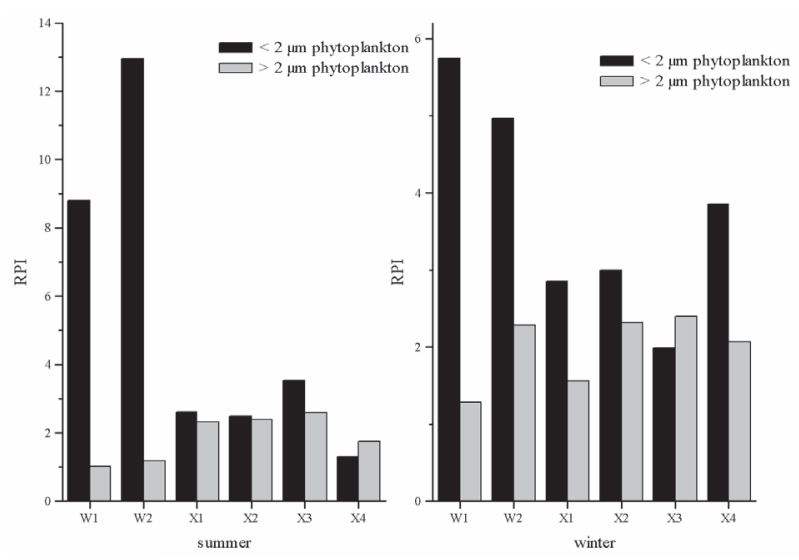

Fig. 3. Relative preference index (RPI) of microzooplankton selective grazing on differently sized phytoplankton; the number of replicates was 3 .

picophytoplankton $(<2 \mu \mathrm{m})$ was positively correlated with microzooplankton grazing rate on larger phytoplankton ( $>2 \mu \mathrm{m} m, \mathrm{r}=0.68, p<0.05)$ and larger phytoplankton growth rate $(>2 \mu \mathrm{m} \mu, \mathrm{r}=0.68, p<0.05)$. In addition, microzooplankton grazing rate on picophytoplankton $(<2 \mu \mathrm{m} m)$ and $>2 \mu \mathrm{m} \mu$ were positively correlated $(\mathrm{r}=0.60, p<0.05)$.

\section{Discussion}

\section{Phytoplankton Community Structure under Conditions of High N:P Ratio}

Phytoplankton grows fast and has high nutrient requirements, but its biomass is often nutrient limited
[21-22]. However, the nutriment requirements of rooted macrophytes are lower than those of microalgae because of low growth rates, high internal C:N:P ratios, and the existence of nutrient-conserving mechanisms; furthermore, the nutrient limitation is less important because the plants exploit the rich nutrient pools of the sediment [23-24]. And phytoplankton dominates in nutriment-rich shallow waters because of shading effects on macrophytes and benthic microalgae [25]. Nitrogen (N) was the main limiting nutrient for algal growth, and fast-growing algae were $\mathrm{N}$ limited for a longer period than slower-growth species [26-27]. While other study results indicated low phosphorus (P) nutrient concentrations, zooplankton grazing pressure on phytoplankton was high and phytoplankton biomass was low, but submerged macrophyte abundance was high [28]. With increasing $\mathrm{TP}$, phytoplankton biomass and $\mathrm{Chl}$ a increased 15-fold and submerged macrophytes disappeared from most lakes [29]. Besides, some studies found that $\mathrm{P}$ concentration and water temperature were the key factors controlling the outbreak of summer cyanobacterial bloom in West Lake [30]. The N:P in the water body was of great significance to the algae overgrowth, because when N:P was less than 7 10, the growth of algae was limited by nitrogen; when the N:P ratio was greater than 22.6 30, $\mathrm{P}$ was the limiting factor in the growth of algae; and when the N:P ratio was between the condition of the above two, it was the suitable range for algae growth, especially where the N:P ratio was about 12 , the algae growth cycle was the shortest, and the production was the most [31]. Waihu had high phytoplankton density and no submerged macrophytes were found, especially the Chl a concentration in Waihu was significantly higher than in Xilihu. However, Xilihu Lake was in a clear water state that submerged vegetation perennial growth

Table 3. Microzooplankton grazing rate on total phytoplankton $\left(m\right.$, day $\left.^{-1}\right)$ and total phytoplankton growth rate $\left(\mu\right.$, day $\left.{ }^{-1}\right)$ of all in-situ dilution experiment sites in Waihu and Xilihu during summer and winter (se, standard error; $R^{2}$, the determination coefficient of the regression of the linear part; $N$, the number of data points in the linear part; $p$, the significant level of the regression of the linear part).

\begin{tabular}{|c|c|c|c|c|c|c|}
\hline Season & Station & $m \pm \mathrm{se}$ & $\mu \pm \mathrm{se}$ & $R^{2}$ & $N$ & $p$ \\
\hline \multirow{5}{*}{ Summer } & $\mathrm{X} 1$ & $2.83 \pm 0.48$ & $2.46 \pm 0.29$ & 0.81 & 10 & $<0.001$ \\
\cline { 2 - 7 } & $\mathrm{X} 2$ & $2.25 \pm 0.45$ & $1.93 \pm 0.28$ & 0.76 & 10 & 0.001 \\
\cline { 2 - 7 } & $\mathrm{X} 3$ & $1.81 \pm 0.33$ & $1.86 \pm 0.20$ & 0.79 & 10 & 0.001 \\
\cline { 2 - 7 } & $\mathrm{X} 4$ & $3.25 \pm 0.56$ & $3.05 \pm 0.35$ & 0.81 & 10 & $<0.001$ \\
\cline { 2 - 7 } & $\mathrm{W} 1$ & $2.88 \pm 0.34$ & $2.47 \pm 0.21$ & 0.90 & 10 & $<0.001$ \\
\cline { 2 - 7 } & $\mathrm{W} 2$ & $2.49 \pm 0.31$ & $2.28 \pm 0.19$ & 0.91 & 8 & $<0.001$ \\
\hline \multirow{5}{*}{ Winter } & $\mathrm{X} 1$ & $2.55 \pm 0.35$ & $2.38 \pm 0.21$ & 0.87 & 10 & $<0.001$ \\
\cline { 2 - 7 } & $\mathrm{X} 2$ & $2.12 \pm 0.19$ & $1.97 \pm 0.12$ & 0.94 & 10 & $<0.001$ \\
\cline { 2 - 7 } & $\mathrm{X} 3$ & $1.87 \pm 0.48$ & $1.72 \pm 0.30$ & 0.65 & 10 & 0.005 \\
\cline { 2 - 7 } & $\mathrm{X} 4$ & $1.58 \pm 0.48$ & $1.38 \pm 0.29$ & 0.58 & 10 & 0.011 \\
\cline { 2 - 7 } & $\mathrm{W} 1$ & $3.33 \pm 0.46$ & $2.59 \pm 0.22$ & 0.90 & 8 & $<0.001$ \\
\cline { 2 - 7 } & $\mathrm{W} 2$ & $2.56 \pm 0.38$ & $2.11 \pm 0.19$ & 0.90 & 8 & 0.001 \\
\hline
\end{tabular}


in water. According to the analysis of water quality in Waihu and Xiihu, the N:P ratio of Waihu in summer was the lowest (11.45), and the N:P ratio of Waihu in winter was 46.12. However, $\mathrm{N}: \mathrm{P}$ ratios greater than 30 remained in Xilihu during 2 seasons. The suitable N:P ratio and lack of submerged macrophytes were probably one of the reasons leading to blooms of phytoplankton growth in the summer in Waihu.

Through analysis of the phytoplankton size composition, it was found that when Waihu was in high phytoplankton concentrations, the phytoplankton was dominated by the larger-sized phytoplankton. This phenomenon was consistent with the results of Wong et al. [32]. But the Chl a concentration in Xilihu, as a natural restoration of submerged vegetation lake, was much lower, and the more interesting phenomenon was that there were no significant differences between the $\mathrm{Chl}$ a concentration of larger phytoplankton and picophytoplankton. This indicates that the restoration of submerged vegetation promoted the water ecological balance of Xilihu.

\section{Microzooplankton Grazing and Phytoplankton Growth in West Lake}

In this investigation, the microzooplankton grazing rates were $1.58 \sim 3.33 / \mathrm{d}$ and phytoplankton growth rates were 1.38 3.05/d in West Lake. Calbet et al. [17] determined that the microzooplankton grazing rates were $0.44 \sim 0.97 / \mathrm{d}$ and phytoplankton growth rates were $0.16 \sim 0.53 / \mathrm{d}$ in the oceans. First et al. [33] studied the Texas coast area and found that the microzooplankton grazing rates were $-0.01 \sim 1.76 / \mathrm{d}$ and phytoplankton growth rates were $-0.28 \sim 1.64 /$ d. Abbate et al. [3] demonstrated that the microzooplankton grazing rates were $0 \sim 5.20 / \mathrm{d}$ and phytoplankton growth rates were $0 \sim 3.83 / \mathrm{d}$ in the estuary area. Wong et al. [32] studied 3 shallow coastal lakes in estuary areas, and found the microzooplankton grazing rates to be $0 \sim 0.63 / \mathrm{d}$ and phytoplankton growth rates $0.12 \sim 1.84$ /d. The results of this study suggested higher microzooplankton grazing rates and phytoplankton growth rates in the freshwater eutrophic lake than those in marine areas. This may be

Table 4. Microzooplankton grazing rate on different sized phytoplankton $\left(m\right.$, day $\left.^{-1}\right)$ and phytoplankton growth rates $\left(\mu\right.$, day $\left.{ }^{-1}\right)$ of all in-situ dilution experiment sites in Waihu and Xilihu during summer and winter $(<2 \mu \mathrm{m}$, the picophytoplankton; $>2 \mu \mathrm{m}$, the larger phytoplankton; se, standard error; $R^{2}$, the determination coefficient of the regression of the linear part; $N$, the number of data points in the linear part; $p$, the significant level of the regression of the linear part).

\begin{tabular}{|c|c|c|c|c|c|c|c|}
\hline Size-fraction & Season & Station & $m$ & $\mu$ & $R^{2}$ & $N$ & $p$ \\
\hline \multirow{12}{*}{$<2 \mu \mathrm{m}$} & \multirow{6}{*}{ summer } & $\mathrm{X} 1$ & $3.67 \pm 0.42$ & $2.91 \pm 0.26$ & 0.86 & 15 & $<0.001$ \\
\hline & & $\mathrm{X} 2$ & $3.05 \pm 0.59$ & $2.32 \pm 0.34$ & 0.69 & 14 & $<0.001$ \\
\hline & & $\mathrm{X} 3$ & $2.47 \pm 0.47$ & $2.29 \pm 0.29$ & 0.68 & 15 & $<0.001$ \\
\hline & & $\mathrm{X} 4$ & $3.92 \pm 0.76$ & $3.74 \pm 0.47$ & 0.67 & 15 & $<0.001$ \\
\hline & & W1 & $2.69 \pm 0.29$ & $2.44 \pm 0.18$ & 0.87 & 15 & $<0.001$ \\
\hline & & W2 & $2.82 \pm 0.74$ & $2.42 \pm 0.45$ & 0.53 & 15 & 0.002 \\
\hline & \multirow{6}{*}{ winter } & $\mathrm{X} 1$ & $2.89 \pm 0.28$ & $2.89 \pm 0.17$ & 0.93 & 10 & $<0.001$ \\
\hline & & $\mathrm{X} 2$ & $3.49 \pm 0.61$ & $2.95 \pm 0.38$ & 0.80 & 10 & $<0.001$ \\
\hline & & $\mathrm{X} 3$ & $1.61 \pm 0.26$ & $1.56 \pm 0.16$ & 0.83 & 10 & $<0.001$ \\
\hline & & $\mathrm{X} 4$ & $2.81 \pm 0.83$ & $2.43 \pm 0.51$ & 0.59 & 10 & 0.009 \\
\hline & & W1 & $3.54 \pm 0.68$ & $2.74 \pm 0.32$ & 0.82 & 8 & 0.002 \\
\hline & & W2 & $2.43 \pm 0.48$ & $2.05 \pm 0.24$ & 0.84 & 7 & 0.004 \\
\hline \multirow{12}{*}{$>2 \mu \mathrm{m}$} & \multirow{6}{*}{ summer } & $\mathrm{X} 1$ & $3.24 \pm 0.42$ & $2.93 \pm 0.26$ & 0.82 & 15 & $<0.001$ \\
\hline & & $\mathrm{X} 2$ & $2.51 \pm 0.39$ & $2.40 \pm 0.24$ & 0.76 & 15 & $<0.001$ \\
\hline & & $\mathrm{X} 3$ & $2.41 \pm 0.42$ & $2.44 \pm 0.26$ & 0.73 & 14 & $<0.001$ \\
\hline & & $\mathrm{X} 4$ & $2.51 \pm 0.29$ & $2.58 \pm 0.18$ & 0.86 & 14 & $<0.001$ \\
\hline & & W1 & $2.51 \pm 0.26$ & $2.27 \pm 0.16$ & 0.88 & 15 & $<0.001$ \\
\hline & & W2 & $2.47 \pm 0.38$ & $2.17 \pm 0.23$ & 0.78 & 14 & $<0.001$ \\
\hline & \multirow{6}{*}{ winter } & $\mathrm{X} 1$ & $1.89 \pm 0.42$ & $1.62 \pm 0.26$ & 0.72 & 10 & 0.002 \\
\hline & & $\mathrm{X} 2$ & $2.34 \pm 0.50$ & $2.20 \pm 0.31$ & 0.73 & 10 & 0.002 \\
\hline & & $\mathrm{X} 3$ & $1.48 \pm 0.64$ & $1.44 \pm 0.39$ & 0.40 & 10 & 0.05 \\
\hline & & $\mathrm{X} 4$ & $1.75 \pm 0.45$ & $1.65 \pm 0.28$ & 0.65 & 10 & 0.005 \\
\hline & & W1 & $3.63 \pm 0.47$ & $2.80 \pm 0.22$ & 0.91 & 8 & $<0.001$ \\
\hline & & W2 & $3.47 \pm 0.41$ & $2.66 \pm 0.19$ & 0.92 & 8 & $<0.001$ \\
\hline
\end{tabular}




\begin{tabular}{|c|c|c|c|c|c|c|c|c|c|c|c|c|c|c|c|c|}
\hline $\begin{array}{l}\vec{z} \\
\underline{\Xi} \\
\vec{v} \\
v\end{array}$ & & & & & & & & & & & & & & & & \\
\hline $\begin{array}{c}\Xi \\
\Xi \\
\underline{\Xi} \\
\vec{V} \\
V\end{array}$ & & & & & & & & & & & & & & & - & $\begin{array}{l}* \\
\text { *. } \\
\text { \&̊ } \\
\text { o }\end{array}$ \\
\hline $\begin{array}{l}\vec{z} \\
\underline{\Xi} \\
\stackrel{\Lambda}{\wedge}\end{array}$ & & & & & & & & & & & & & & & \begin{tabular}{c}
$*$ \\
\multirow{2}{*}{} \\
0 \\
0 \\
0
\end{tabular} & $\begin{array}{c}\tilde{N} \\
\infty \\
\tilde{0}\end{array}$ \\
\hline 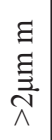 & & & & & & & & & & & & - & & 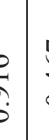 & $\begin{array}{l}\widehat{0} \\
\vdots \\
0 \\
0\end{array}$ & $\frac{n}{\grave{\sigma}}$ \\
\hline $\begin{array}{l}\frac{z}{\pi} \\
\frac{\vec{\sigma}}{0} \\
\hat{\theta}\end{array}$ & & & & & & & & & & & - & ğ & & ? & 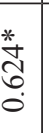 & $\begin{array}{l}\stackrel{*}{\circ} \\
0\end{array}$ \\
\hline 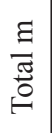 & & & & & & & & & & - & \begin{tabular}{l}
$*$ \\
$*$ \\
\multirow{2}{*}{} \\
0
\end{tabular} & $\mid \begin{array}{l}* \\
\tilde{G} \\
\sigma \\
0\end{array}$ & & 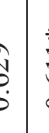 & 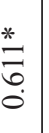 & 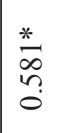 \\
\hline 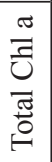 & & & & & & & & & - & $\begin{array}{l}\stackrel{\circ}{?} \\
\stackrel{0}{0}\end{array}$ & $\frac{\tilde{n}}{0}$ & I & & 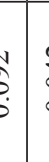 & 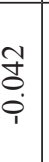 & $\underset{\Xi}{=}$ \\
\hline 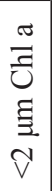 & & & & & & & & - & 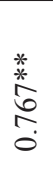 & 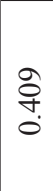 & $\frac{7}{3}$ & $\mid \begin{array}{l}* \\
\text { *a } \\
\stackrel{\alpha}{\alpha}\end{array}$ & & $\begin{array}{l}0 \\
\vdots \\
0 \\
b\end{array}$ & 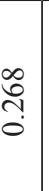 & $\begin{array}{l}\overrightarrow{8} \\
\stackrel{i}{i}\end{array}$ \\
\hline 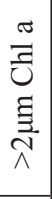 & & & & & & & - & $\begin{array}{l}\stackrel{*}{*} \\
\stackrel{*}{*} \\
\infty \\
0 \\
0\end{array}$ & 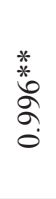 & ते & $\begin{array}{l}n \\
\tilde{z} \\
z\end{array}$ & $\frac{2}{2}$ & & b. & $\begin{array}{l}\stackrel{m}{7} \\
\vdots \\
i\end{array}$ & $\begin{array}{l}\infty \\
\stackrel{1}{1} \\
\end{array}$ \\
\hline$Z$ & & & & & - & & 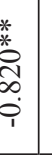 & $\begin{array}{l}\text { * } \\
\stackrel{*}{*} \\
\stackrel{0}{i}\end{array}$ & 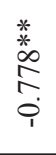 & 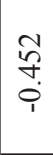 & \begin{tabular}{l}
$n$ \\
\multirow{7}{7}{} \\
9
\end{tabular} & 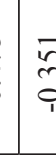 & & $\begin{array}{l}0 \\
t \\
⿱ 亠 䒑 \\
\end{array}$ & $\begin{array}{l}\hat{a} \\
\text { in } \\
i\end{array}$ & $\begin{array}{l}\overline{0} \\
\text { : } \\
\text { in }\end{array}$ \\
\hline$\tilde{F}$ & & & & - & 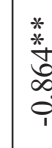 & $\dot{b}$ & $\begin{array}{l}* \\
* \\
* \\
\vdots \\
\vdots \\
\vdots \\
\vdots \\
\vdots\end{array}$ & $\begin{array}{l}\stackrel{*}{*} \\
\stackrel{0}{0} \\
\stackrel{0}{0}\end{array}$ & \begin{tabular}{l}
$*$ \\
\multirow{2}{*}{} \\
$\stackrel{+}{+}$ \\
$\dot{0}$
\end{tabular} & $\begin{array}{l}n \\
\tilde{n} \\
0\end{array}$ & \begin{tabular}{l}
$*$ \\
\multirow{2}{0}{} \\
$i$ \\
$a$
\end{tabular} & 守 & & $\begin{array}{l}y_{0}^{2} \\
0 \\
0 \\
0\end{array}$ & 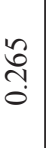 & $\stackrel{\infty}{0}$ \\
\hline 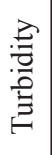 & & & - & 逆 & $\begin{array}{l}* \\
* \\
\infty \\
\infty \\
0 \\
0 \\
i\end{array}$ & 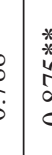 & 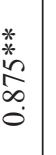 & $\begin{array}{l}\hat{b} \\
\stackrel{n}{0}\end{array}$ & 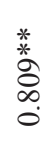 & 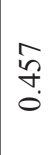 & శై & ${ }_{\mathfrak{f}}^{\infty}$ & & $\vec{b}$ & $\begin{array}{l}\underset{ \pm}{ \pm} \\
\stackrel{i}{i}\end{array}$ & 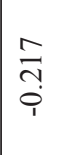 \\
\hline § & & - & 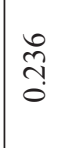 & $\frac{7}{7}$ & $\frac{2}{3}$ & & $\begin{array}{l}0 \\
\vdots \\
0 \\
0\end{array}$ & $\begin{array}{l}\stackrel{\text { d }}{\mathrm{i}} \\
\stackrel{i}{i}\end{array}$ & : & 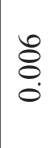 & 고 & 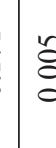 & & $\begin{array}{l}0 \\
\vdots \\
\vdots \\
1\end{array}$ & 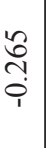 & 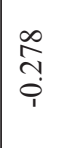 \\
\hline 5 & - & 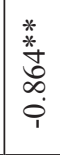 & $\stackrel{\check{\beth}}{\tilde{0}}$ & \begin{tabular}{l}
$*$ \\
$*$ \\
$*$ \\
\multirow{2}{*}{} \\
0
\end{tabular} & $\begin{array}{l}* \\
\text { * } \\
\tilde{c} \\
\text { c. }\end{array}$ & & $\begin{array}{l}\hat{o} \\
+ \\
0\end{array}$ & $\stackrel{\infty}{\stackrel{\infty}{+}}$ & Ĩ & त̂ & $\begin{array}{l}\tilde{0} \\
\tilde{c}\end{array}$ & $\frac{\Omega}{0}$ & & $\begin{array}{l}y \\
y \\
b \\
b\end{array}$ & \begin{tabular}{l}
0 \\
$\stackrel{0}{t}$ \\
\hdashline \\
0
\end{tabular} & 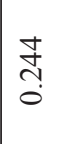 \\
\hline & 5 & $\stackrel{̊}{\circ}$ & 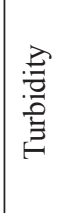 & $\hat{\imath}$ & $z$ & & 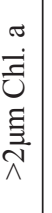 & 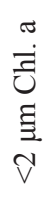 & 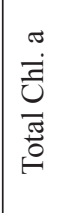 & 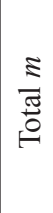 & 齐 & 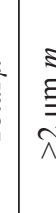 & & 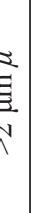 & $\begin{array}{c}\Xi \\
\Xi \\
\underline{\Xi} \\
\vec{V}\end{array}$ & 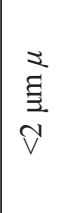 \\
\hline
\end{tabular}




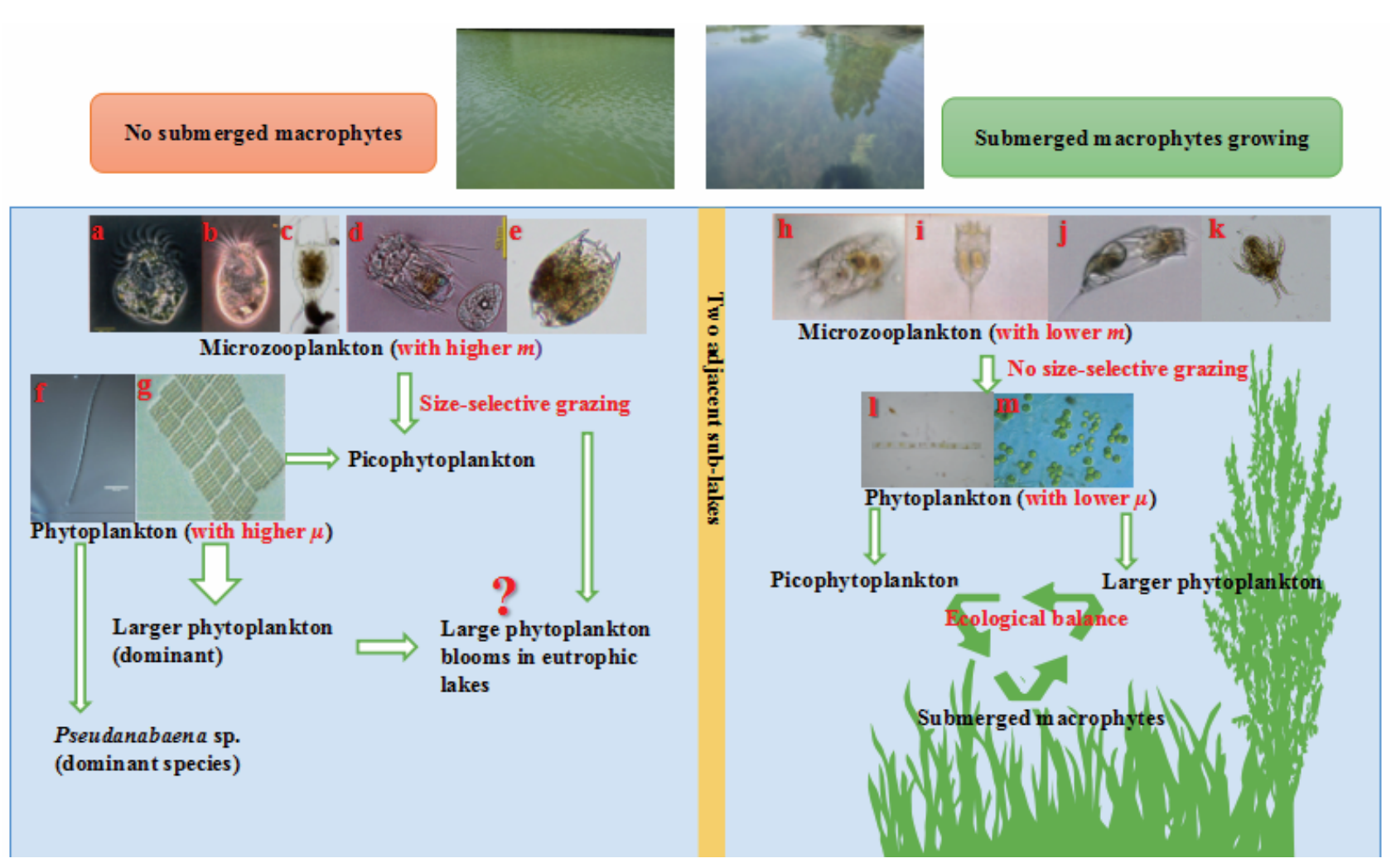

Fig. 4. Schematic diagram of the influencing mechanism of submerged macrophytes and size-selective grazing by microzooplankton on large phytoplankton blooms in eutrophic lakes: a, ciliates; b, ciliates; c, Brachionus sp.1; d, Polyarthra sp.; e, Brachionus sp.2; f, Pseudanabaena sp.; g, Cyanobacteria; h, KeratelIa sp.1,; i, Keratella sp.2; j, Trichocerca sp.; k, nauplii; 1, diatoms; m, green algae.

due to differences in the trophic status of water bodies and in plankton community structure.

\section{Microzooplankton Size-Selective Grazing}

Microzooplankton has dominant selective grazing on different size phytoplankton. In the South China Sea, microzooplankton preferred to graze on larger ( $>3 \mu \mathrm{m})$ phytoplankton in comparison with smaller $(<3 \mu \mathrm{m})$ phytoplankton [7]. Wong et al. [32] studied 3 shallow coastal lakes and found that microzooplankton grazing rates on the slower growing, small phytoplankton $(<5 \mu \mathrm{m})$ were higher than on the larger phytoplankton $(<20 \mu \mathrm{m})$, which had relatively faster growth rates. The relative weakness of top-down grazing control on larger phytoplankton by microzooplankton and the relatively fast growth of larger phytoplankton might be why the average size of phytoplankton tends to increase in these eutrophic waters [32]. In these dilution experiments, microzooplankton showed positive grazing on picophytoplankton $(<2 \mu \mathrm{m})$ in West Lake. Meanwhile, in Waihu, the RPI index of microzooplankton grazing on picophytoplankton was significantly higher than the RPI index of microzooplankton grazing on larger phytoplankton. Meanwhile, the Chl a concentration of larger phytoplankton was significantly higher than that of picophytoplankton, which could just confirm the above results.

\author{
Effects of Submerged Macrophytes \\ on Microzooplankton Grazing Rate \\ and Phytoplankton Growth Rate
}

Submerged macrophytes are important and crucial for stabilizing the clear water state in eutrophic lakes [34]. As one of the important measures in the eutrophic water ecological restoration project, submerged vegetation reconstruction was effective [35-37]. The implementation of this technique had an important influence on the nutrients and plankton community structure in fresh water [38-39]. For example, submerged macrophytes of Vallisneria natans, Ceratophyllum demersum, and Myriophyllum spicatum could release a variety of allelochemicals, which could significantly inhibit algae growth and reduce the $\mathrm{Chl}$ a concentration [40-41]. The presence of macrophytes in mesotrophic to eutrophic lakes has a positive effect on zooplankton biomass and a negative effect on phytoplankton biomass. Zooplankton grazing in macrophyte beds may play a major role in controlling phytoplankton [42-43]. Besides, floating fragments of submerged macrophytes competed with algae for nutrients, occupying a favorable ecological niche and reducing algae biomass. They could alter the structure of the algae community and shift the dominated green algae to cyanobacteria (the green algae of phytoplankton) and benthic algae [38]. The dominant species in Waihu was Pseudanabaena sp. (filamentous algae). 
But phytoplankton in Xilihu varied and was mainly composed of diatoms and green algae, and the density of phytoplankton was significantly lower than that in Waihu. This indicates that the reconstruction of submerged vegetation could effectively change the phytoplankton community structure, and decrease the phytoplankton biomass and the $\mathrm{Chl}$ a concentration.

In winter, both microzooplankton grazing rates and phytoplankton growth rates in Waihu were significantly higher than in Xilihu, but in summer no significant difference existed. In addition, a correlation analysis showed that the value of $m$ was positively related to the $\mu$, which was consistent with the studies of Zhou et al. [7]. The growth rate of larger $(>2 \mu \mathrm{m})$ phytoplankton and microzooplankton grazing rates on picophytoplankton were correlated, which might be able to explain a decrease of picophytoplankton with increasing microzooplankton grazing rates on picophytoplankton, thereby leading to the larger phytoplankton growth rate increased by providing more nutrients, spaces, and ecological niches for larger phytoplankton. The Chl a concentration of picophytoplankton was positively correlated with the Chl a concentration of larger phytoplankton, the microzooplankton grazing rate on larger phytoplankton, and the larger phytoplankton growth rate. It showed that picophytoplankton could affect the growth of larger phytoplankton.

Overall, owing to a lack of competition between submerged macrophytes and algae, the density of phytoplankton was higher in Waihu. At the same time, microzooplankton had a stronger control over picophytoplankton and lacked control over larger phytoplankton, which might result in large phytoplankton blooms in eutrophic lakes (Fig. 4). Furthermore, submerged macrophytes affected the density and community structure of phytoplankton in Xilihu, where submerged macrophytes were dominant and the water transparency was high. There was no significant difference between the proportions of differently sized phytoplankton in Xilihu.

\section{Conclusions}

Microzooplankton grazing could affect the phytoplankton community structure. In freshwater West Lake, the $m$ ranged from $1.58 \sim 3.33 / \mathrm{d}$, and the $\mu$ ranged from $1.38 \sim 3.05 / \mathrm{d}$, which were higher than those of the ocean areas. In Waihu, without the existence of submerged macrophytes, the $m$ and $\mu$ were higher than those in Xilihu, with naturally growing submerged macrophytes. Higher RPI for picophytoplankton than larger phytoplankton indicated that size-selective grazing by microzooplankton on picophytoplankton was significant in Waihu. However, there was no significant size-selection in Xilihu. Lacking competition between submerged macrophytes and algae and microzooplankton, the grazing effect on picophytoplankton might result in large phytoplankton blooms in eutrophic lakes.

\section{Acknowledgements}

This study was supported by the Major Science and Technology Program for Water Pollution Control and Treatment of China 13th Five-Year Plan (No. 2017ZX07602-002-004) and the Major Projects of Technical Innovation of Hubei Province (2016ACA169). We thank Shuangyuan Liu, Qi Wang, Fenli Min, Qingwei Lin, Xianfen Xiang, and Liping Zhang for their assistance.

\section{Conflict of Interest}

The authors declare no conflict of interest.

\section{References}

1. LENZ J. Microbial loop, microbial food web and classical food chain: Their significance in pelagic marine ecosystems. Arch. Hydrobiol. Beih. Ergebn. Limnol. 37, 265, 1992.

2. SAILLEY S.F., BUITENHUIS E.T. Microzooplankton functional responses in the lab and in the field. Earth Syst. Sci. Data Discuss. 7 (1), 149, 2014.

3. ABBATE M.C.L., DE CAO M.S.B., PETTIGROSSO R.E., GUINDER V.A., DUTTO M.S., BERASATEGUI A.A., CHAZARRETA C.J., HOFFMEYER M.S. Seasonal changes in microzooplankton feeding behavior under varying eutrophication level in the Bahía Blanca estuary (SW Atlantic Ocean). J. Exp. Mar. Biol. Ecol. 481, 25, 2016.

4. CALBET A., LANDRY M.R. Phytoplankton growth, microzooplankton grazing, and carbon cycling in marine systems. Limnol. Oceanogr. 49 (1), 51, 2004.

5. GRINIENE E., ŠULČIUS S., KUOSA H. Size-selective microzooplankton grazing on the phytoplankton in the Curonian Lagoon (SE Baltic Sea). Oceanologia. 58 (4), 292, 2016.

6. YANG E.J., HA H.K., KANG S.H. Microzooplankton community structure and grazing impact on major phytoplankton in the Chukchi Sea and the western Canada Basin, Arctic Ocean. Deep-Sea Res. II. 120, 91, 2015.

7. ZHOU L., TAN Y., HUANG L., HU Z., KE Z. Seasonal and size-dependent variations in the phytoplankton growth and microzooplankton grazing in the southern South China Sea under the influence of the East Asian monsoon. Biogeosciences. 12 (22), 6809, 2015.

8. DIODATO S.L., HOFFMEYER M.S. Contribution of planktonic and detritic fractions to the natural diet of mesozooplankton in Bahía Blanca Estuary. Hydrobiologia. 614 (1), 83, 2008.

9. SUN J., FENG Y., ZHANG Y., HUTCHINS D.A. Fast microzooplankton grazing on fast-growing, low-biomass phytoplankton: a case study in spring in Chesapeake Bay, Delaware Inland Bays and Delaware Bay. Hydrobiologia. 589 (1), 127, 2007.

10. BURIAN A., SCHAGERL M., YASINDI A. Microzooplankton feeding behaviour: grazing on the microbial and the classical food web of African soda lakes. Hydrobiologia. 710 (1), 61, 2013.

11. SAHU B.K., SRICHANDAN S., PANIGRAHY R.C. A preliminary study on the microzooplankton of Chilika 
Lake, a brackish water lagoon on the east coast of India. Environ. Monit. Assess. 188 (1), 69, 2016.

12. ZHANG Y., LIU X., QIN B., SHI K., DENG J., ZHOU Y. Aquatic vegetation in response to increased eutrophication and degraded light climate in Eastern Lake Taihu: Implications for lake ecological restoration. Sci. Rep. 6, 23867, 2016.

13. STATE EPA OF CHINA (ED.). Monitoring and determination methods for water and wastewater, $4^{\text {th }}$ ed. China Environmental Science Press, Beijing, 2002 [In Chinese].

14. CHEN Q. Most common freshwater algal images of Zhejiang province(drinking water sources). China Environmental Science Press, Beijing, 2010 [In Chinese].

15. WANG J.J. Freshwater rotifers of China. Science Press, Beijing, 1961 [In Chinese].

16. SHEN Y.F., ZHANG Z.S., GONG X.J. New monitoring technology of microorganism. China Construction Press, Beijing, 1990 [In Chinese].

17. CALBET A., SAIZ E. Effects of trophic cascades in dilution grazing experiments: from artificial saturated feeding responses to positive slopes. J. Plankton Res. 35 (6), 1183, 2013.

18. LANDRY M.R., KIRSHTEIN J., CONSTANTINOU J. A refined dilution technique for measuring the community grazing impact of microzooplankton, with experimental tests in the central equatorial Pacific. Mar. Ecol. Prog. Ser. Oldendorf. 120 (1), 53, 1995.

19. APPLE J.K., STROM S.L., PALENIK B., BRAHAMSHA B. Variability in protist grazing and growth on different marine Synechococcus isolates. Appl. Environ. Microb. 77 (9), 3074, 2011

20. OBAYASHI Y., TANOUE E. Growth and mortality rates of phytoplankton in the northwestern North Pacific estimated by the dilution method and HPLC pigment analysis. J.Exp. Mar. Biol. Ecol. 280 (1), 33, 2002.

21. MARAÑÓN E., CERMEÑO P., LÓPEZ-SANDOVAL D. C., RODRÍGUEZ-RAMOS T., SOBRINO C., HUETE-ORTEGA M., RODRÍGUEZ J. Unimodal size scaling of phytoplankton growth and the size dependence of nutrient uptake and use. Ecol. Lett. 16 (3), 371, 2013.

22. MOORE C.M., MILLS M.M., ARRIGO K.R., BERMAN-FRANK I., BOPP L., BOYD P.W., JICKELLS T.D. Processes and patterns of oceanic nutrient limitation. Nat. Geosci. 6 (9), 701, 2013.

23. NÕGES T., LUUP H., FELDMANN T. Primary production of aquatic macrophytes and their epiphytes in two shallow lakes (Peipsi and Võrtsjärv) in Estonia. Aquat. Ecol. 44 (1), 83, 2010.

24. KÖHLER J., HACHOŁ J., HILT S. Regulation of submersed macrophyte biomass in a temperate lowland river: Interactions between shading by bank vegetation, epiphyton and water turbidity. Aquat. Bot. 92 (2), 129, 2010.

25. GUDMUNDSDOTTIR R., OLAFSSON J.S., PALSSON S., GISLASON G.M., MOSS B. How will increased temperature and nutrient enrichment affect primary producers in sub-Arctic streams? Freshwater Biol. 56 (10), 2045, 2011.

26. CLAUSING R.J., FONG P. Environmental variability drives rapid and dramatic changes in nutrient limitation of tropical macroalgae with different ecological strategies. Coral Reefs. 35 (2), 669, 2016.

27. WANG C., LEI A.P., ZHOU K., HU Z.Y., HAO W.L., YANG J.D. Growth and Nitrogen Uptake Characteristics
Reveal Outbreak Mechanism of the Opportunistic Macroalga Gracilaria tenuistipitata. PloS One. 9 (10), 2014.

28. CHRIATIANSEN N.H., ANDERSEN F.O., JENSEN H.S. Phosphate uptake kinetics for four species of submerged freshwater macrophytes measured by a P-33 phosphate radioisotope technique. Aquat. Bot. 128, 58, 2015.

29. JEPPESEN E., PEDER JENSEN, J., SØNDERGAARD M., LAURIDSEN T., LANDKILDEHUS F. Trophic structure, species richness and biodiversity in Danish lakes: changes along a phosphorus gradient. Freshwater Biol. 45 (2), 201, 2000.

30. SONG H., XU J.H., LAVOIE M., FAN X.J., LIU G.F., SUN L.W., FU Z.W. QIAN H.F. Biological and chemical factors driving the temporal distribution of cyanobacteria and heterotrophic bacteria in a eutrophic lake (West Lake, China). Appl. Microbiol. Biot. 101, 1685, 2017.

31. NIE Z.Y., LIANG X.Q., XING B., YE Y.S., QIAN Y.C., YU Y.W., BIAN J.Y., GU J.T., CHEN Y. The current water trophic status in Tiaoxi River of Taihu Lake watershed and corresponding coping strategy based on N/P ratio analysis. Acta Ecol. Sin. 32 (1), 48, 2012 [In Chinese].

32. WONG W.H., RABALAIS N.N., TURNER R.E. Sizedependent top-down control on phytoplankton growth by microzooplankton in eutrophic lakes. Hydrobiologia. $\mathbf{7 6 3}$ (1), 97, 2016.

33. FIRST M.R., LAVRENTYEV P.J., JOCHEM F.J. Patterns of microzooplankton growth in dilution experiments across a trophic gradient: Implications for herbivory studies. Mar. Biol. 151 (5), 1929, 2007.

34. ZHOU X.Z., HE Z.L., JONES K.D., LI L.G., STOFFELLA P.J. Dominating aquatic macrophytes for the removal of nutrients from waterways the Indian River Lagoon basin, South Florida, USAXiaohong. Ecol. Eng. 101, 107, 2017.

35. ZENG L., HE F., ZHANG Y., LIU B.Y., DAI Y.R., ZHOU Q.H., WU Z.B. How submerged macrophyte restoration promotes a shift of phytoplankton community in a shallow subtropical lake. Pol. J. Environ.Stud. 26 (3), 1363, 2017.

36. SUN J., MA L., WANG L., HU Y., ZHANG Y., WU Z.B., HE F. Assessing the Effects of Grass Carp Excretion and Herbivory of Submerged Macrophytes on Water Quality and Zooplankton Communities. Pol. J. Environ. Stud. 26 (4), 1681, 2017.

37. CIURLI A., ZUCCARINI P., ALPI A. Growth and nutrient absorption of two submerged aquatic macrophytes in mesocosms, for reinsertion in a eutrophicated shallow lake. Wetl. Ecol. Manag. 17 (2), 107, 2009.

38. ZHOU Y., ZHOU X., HAN R., XU X., WANG G., LIU X., BI F.Z., FENG D. Reproduction capacity of Potamogeton crispus fragments and its role in water purification and algae inhibition in eutrophic lakes. Sci. Total Environ. 580, 1421, 2017.

39. WANG H.Q., LIANG F., ZHANG L.Y. Composition and Anti-Cyanobacterial Activity of Essential Oils from Six Different Submerged Macrophytes. Pol. J. Environ. Stud. 24 (1), 333, 2015.

40. YAO Y., HE F., HU S.H., KONG L.W., LIU B.Y., ZENG L., ZHANG L.P., WU Z.B. Effects of allelopathy of submerged macrophytes on the phytoplankton community collected from the west part of the West Lake wetland in Hangzhou, China. Acta Ecol. Sin. 36 (4), 971, 2016 [In Chinese].

41. AKHURST D.J., JONES G.B., CLARK M., REICHELTBRUSHETT A. Effects of fish and macrophytes 
on phytoplankton and zooplankton community structure in a subtropical freshwater reservoir. Limnology. 62, 5, 2017.

42. MUYLAERT K., PEREZ-MARTINEZ Z., SANCHEZCASTILLO P., LAURIDSEN T.L., VANDERSTUKKEN M., DECLERCK S.A.J., VAN DER GUCHT K., CONDE-PORCUNA J.M., JEPPESEN E., DE MEESTER L. Influence of nutrients, submerged macrophytes and zooplankton grazing on phytoplanktonbiomass and diversity along a latitudinal gradient in Europe. Hydrobiologia. 653 (1), 79, 2010.

43. SYMONS C.C., ARNOTT S.E., SWEETMAN J.N. Grazing rates of crustacean zooplankton communities on intact phytoplankton communities in Canadian Subarctic lakes and ponds. Hydrobiologia. 694 (1), 131, 2012. 
